
УДК 616-073+616.43

DOI 10.11603/1811-2471.2021.v.i2.12216

\title{
РОЛЬ УЛЬТРАЗВУКОВОЇ ЕЛАСТОГРАФІї ПРИ ОЦІНЦІ ЗАХВОРЮВАНЬ ЩИТОПОДІБНОї ЗАЛОЗИ
}

\author{
○Н. В. Скрипник ${ }^{1}$, Л. В. Рибчак', В. М. Казьмірук², Х. З. Лаврук', \\ А. З. Братина', Т. І. Власюк ${ }^{1}$ \\ 1 1вано-Франківський національний медичний університет \\ 2 Лікувально-діагностичний центр Святого Луки Івано-Франківського Архієпархіального Управління УГКЦ
}

РЕзЮМЕ. В статті зроблено огляд літератури та наведені дані, отримані нами в результаті спостереження за 1549 пацієнтами з патологією щитоподібної залози (ЩЗ) за допомогою зсувнохвильової еластографії на клінічній базі Івано-Франківського національного медичного університету в Лікувально-діагностичному центрі Святого Луки Івано-Франківського Архієпархіального Управління УГКЦ.

Мета - аналіз даних зсувнохвильової еластографії для удосконалення диференційної діагностики патологій щз.

Матеріал і методи. Ультразвукове обстеження проводили на апаратах Siemens Acuson S3000 та Siemens Acuson S2000 з використанням лінійного датчика (з частотою 9 МГц) у В-режимі, режимі кольорової доплерографії та зсувнохвильової еластографії.

Результати. Еластографія відіграє важливу роль у діагностиці та спостереженні за захворюваннями щз. У статті наведені клінічні випадки ехографічних характеристик та зсувнохвильової еластографічної картини доброякісних та злоякісних вузлів, автоімунного тиреоїдиту, дифузного токсичного зоба.

Висновки. Зсувнохвильова еластографія - це новий метод, що розвивається в клінічній практиці, який дозволяє розрізнити доброякісні та злоякісні вузлові утворення ЩЗ, є корисним доповненням для прогнозування злоякісного захворювання, незалежним прогностичним фактором для діагностики раку щз.

КлючовІ СлОВА: щитоподібна залоза; вузлові захворювання щитоподібної залози; зсувнохвильова еластографія; діагностика.

Вступ. Протягом останніх десятиліть світова спільнота приділяє особливу увагу питанням подолання наслідків йодного дефіциту в масштабах планети, розглядаючи його як вирішення однієї 3 глобальних проблем здоров'я людей. Після аварії на ЧАЕС у 1986 р. патологія щитоподібної залози (ЩЗ) посіла перше місце серед усіх ендокринопатій в Україні.

Вузловий та багатовузловий зоб - дуже поширені захворювання, особливо в регіонах, в яких зберігається йододефіцит. За даними великих популяційних досліджень, поширеність вузлів, що пальпуються, складає від 1 до 5 \% в популяції (у 5 \% у жінок і в 1 \% чоловіків). За допомогою ультразвукового дослідження (УЗД) щитоподібної залози у 19-68 \% населення вдається виявити вузлові утворення, які клінічно не були виявлені. Захворювання ЩЗ включають доброякісні та злоякісні вузли, а також дифузні захворювання. Клінічне значення діагностики вузлових утворень полягає в необхідності виключення раку щитоподібної залози (РЩЗ). Частка РЩЗ становить 0,5-1,5\% у структурі всіх злоякісних новоутворень залежно від віку, статі, радіаційного опромінення, спадкового анамнезу та інших факторів. За світовими даними, частота раку Щ3 становить 20-80 випадків на 100 тис. населення на рік, смертність - 5 на 1 млн населення на рік. В Україні, згідно з даними Національного канцер-реєстру України, реєструється близько
3300 нових випадків щорічно, а смертність становить 10-12 на 1 млн населення. Чорнобильська катастрофа додала проблемі нових аспектів, зокрема щодо впливу малих доз опромінення та підвищення захворюваності на РЩз. Вузлові та дифузні ураження ЩЗ часто $\epsilon$ діагностичним викликом для клініцистів. Пальпація $\epsilon$ практичним методом діагностики, однак це дуже суб' єктивний метод, який залежить від розміру та локалізації ураження, а також від майстерності лікаря. У випадках, коли ці вузли дуже малі або розташовані в глибині тканини Щ3, їх виявлення пальпаторно утруднено або навіть $\epsilon$ неможливим. УЗД сканування дозволяє оцінити розташування, контури, форму, структуру, розміри щЗ, наявну внутрішньоорганну патологію, їі характер (дифузний, вогнищевий, кількість утворень і їх характеристики), аномалії, взаємне співвідношення залози з іншими структурами шиї. УзД може допомогти у візуалізації вузлових утворень та дифузних уражень ЩЗ, однак не забезпечує оцінку характеру цих уражень з високою точністю.

Останнім часом активно розробляють різні способи візуалізації зсувних пружних характеристик біологічних м'яких тканин, так звані способи еластографії, які доповнюють традиційні методи візуалізації (ультразвукові, рентгенологічні та радіонуклідні дослідження, магнітно-резонансну томографію тощо) і вважаються перспективними для медичної діагностики патологій тканин. Най- 
Огляди літератури, оригінальні дослідження, погляд на проблему, випадок з практики, короткі повідомлення

більшого поширення набула технологія ультразвукової еластографії, яка полягає у візуалізації тканин і органів із відображенням різниці еластичності (або оберненої характеристики - жорсткості) нормальних і патологічних тканин на основі оцінки локальної деформації при дозованій компресії або вібрації. Еластичність тканини оцінюють за зсувом і деформацією структури у відповідь на навантаження або ж у результаті аналізу появи при цьому зсувних хвиль. Через неоднакову еластичність тканини зазнають деформації різного ступеня. Внаслідок стискання тканин, залежно від ступеня їх еластичності, в отриманому зображенні більш еластичні (м'які) тканини деформуються значно більше, жорсткі (щільні) - меншою мірою [1]. Візуалізація, яка вказує на жорсткість або деформацію тканин за допомогою техніки ультразвукової еластографії, додає нову інформацію, пов'язану з їх структурою. Ця методика дозволяє уникнути малоінвазивного втручання (тонкоголкової аспіраційної пункційної біопсії (ТАПБ) або відтермінувати іiі, хоча необхідність проведення такого втручання, звісно, не заперечується. Низька специфічність традиційного ультразвукового дослідження при диференціюванні доброякісних та злоякісних вузлів ЩЗ призводить до великої кількості непотрібних (тобто при доброякісних вузлах) ТАПБ, що спричиняє значне фінансове та психоемоційне навантаження на пацієнтів.

На сьогодні в Україні тривають дискусії про використання еластографії в диференційній діагностиці захворювань ЩЗ, особливо вогнищевої патології. Дискусії на наукових форумах мають прихильників, противників еластографії щЗ та тих, що сумніваються, тому є необхідність широкого обговорення цієї проблеми.

Мета - аналіз даних зсувнохвильової еластографії для удосконалення диференційної діагностики патологій щЗ.

Матеріал і методи дослідження. Впродовж 2018-2020 років на клінічній базі Івано-Франківського національного медичного університету в Лікувально-діагностичному центрі Святого Луки Івано-Франківського Архієпархіального Управління УГКЦ ми провели 10091 УЗД дослідження щЗ та 1549 досліджень зсувнохвильової еластографії щ3. Ультразвукове обстеження проводили на апараті Siemens Acuson S3000 та Siemens Acuson S2000 з використанням лінійного датчика (з частотою 9 МГц) у В-режимі, режимі кольорової доплерографії та зсувнохвильової еластографії з кольоровим картуванням та вимірюванням швидкості зсувної хвилі (у м/с) при проходженні через паренхіму щитоподібної залози.

Огляд літератури та результати власних досліджень, їх обговорення. Впродовж 2018-
2020 рр. ми провели еластографічне дослідження ЩЗ у 1549 пацієнтів, у них виявлено: доброякісних вузлів - 876, підозрілих на злоякісність - 224, автоімунних тиреоїдитів - 321, випадків дифузного токсичного зоба -128.

Існує два різних методи еластографії, які використовують для дослідження щЗ. Перший метод компресійна еластографія (strain elastography (SE), якісний або напівкількісний метод), для якого використовують силу тиску рук дослідників із датчиком або від пульсацій сонної артерії (квазістатичний). Другий метод - кількісний варіант еластографії за допомогою хвиль зсуву (Shear Wave Elastography (SWE)), при якому датчик індукує ультразвуковий імпульс, формується поперечна хвиля зсуву, яку і вимірюють $[2,3]$. На сьогодні в Україні метод компресійної еластографії $\epsilon$ найдоступішним для комерційних структур, він дозволяє визначити ступінь деформації, вимірюючи значення жорсткості і порівнюючи його з жорсткістю навколишніх тканин. SE - це додатковий модуль, який може бути включений у стандартний УЗД апарат, що дозволяє візуалізувати ЩЗ із визначенням ступеня ії жорсткості. Однак компресія залежить від сили тиску, яку прикладає оператор, тому, щоб оптимізувати процес проведення дослідження, зображення генерується в режимі реального часу на екрані. Отримані значення при SE залежать від сили тиску, яку прикладає оператор та може в деяких випадках дати хибну оцінку жорсткості тканин, що $є$ недоліком даного методу.

Нова технологія ультразвукової зсувнохвильової еластографії називається "електронною пальпацією", оскільки вона забезпечує відтворювану оцінку консистенції тканин. У Сполучених Штатах Америки в 1991 р. Офір та співавт. вперше запропонували використання еластографії [4], а в 2005 р. цей метод застосували для обстеження щитоподібної залози [5]. Про використання SWE для діагностики вузлів щЗ було вперше повідомлено в 2010 p. Sebag et al. [6]. В методиці еластографії за допомогою хвиль зсуву (SWE) використовується ультразвуковий тиск, що генерується датчиком. Це дозволяє стандартизувати силу стиснення. Вимірюється поперечна хвиля зсуву, викликана ультразвуковим імпульсом. Виходячи з формулювання індексу Юнга, еластичність тканин може бути обчислена за допомогою вимірювання швидкості зсуву поперечних хвиль. Залежно від типу SWE кількісна інформація відображається в одиницях швидкості розповсюдження хвилі (м/с) або одиницях тиску, що викликає зсув (кПа). Кількісна характеристика SWE, на відміну від SE, виключає можливість суб'єктивної інтерпретації даних про жорсткість, отриманих за допомогою стандартного ультразвукового імпуль- 
Огляди літератури, оригінальні дослідження, погляд на проблему, випадок з практики, короткі повідомлення су, що переміщує (деформує) тканини. SWE - це технологія, що може надати додаткову інформацію, пов'язану з жорсткістю тканин $[7,8]$. За літературними даними, мета-аналіз 15 досліджень SWE, котрий включав обстеження 1867 пацієнтів із вузлами ЩЗ, продемонстрував, що чутливість та специфічність SWE становили 84,3 \% та 88,4\% відповідно [9]. Мета-аналіз інших досліджень, який включав обстеження 639 пацієнтів з вузлами Щ3, виявив, що SWE є корисним методом для оцінки злоякісності із загальною середньою чутливістю 92 \% та середньою специфічністю 90 \% [10]. Незважаючи на оптимізм щодо цієї методики, деякі автори повідомляють про менш перспективні результати, однак стверджують, що використання цієї техніки візуалізації для вивчення вузлів щз значно розшириться найближчим часом [11].

у рекомендаціях Американської тиреоїдної асоціації (АТА) 2015 року зазначається, що еластографія може бути корисною для передопераційної оцінки ризику раку у пацієнтів [12]. Американська асоціація клінічних ендокринологів 2016 року, Американський коледж ендокринології та керівництво Associazione Medici Endocrinologi Medical (AACE / ACE / AME) зазначили, що еластографія надає інформацію про жорсткість, яка доповнює висновки традиційного УЗД, зокрема, у вузлах з невизначеними цитологічними характеристиками [13]. У рекомендаціях Європейської федерації товариств з ультразвуку в медицині та біології (EFSUMB) 2013 року зазначено, що еластографія може бути використана для спостереження за доброякісними вузлами ЩЗ, діагностованими за допомогою ТПАБ [14]. У 2017 році Всесвітня федерація товариств з ультразвуку в медицині та біології (WFSUMB) опублікувала керівництво з використання еластографічних методів діагностики захворювань щЗ з детальним описом процедури дослідження, результатів та обмежень $[3,15]$. У Міжнародних рекомендаціях з еластографії зазначено, що SWE має високу чутливість та специфічність в діагностиці вузлів Щ3, може бути використана для оцінки жорсткості її паренхіми в диференційній діагностиці доброякісних та злоякісних новоутворень (рекомендації № $16,17,18$ ) [3]. Дослідження Ма та ін. показало, що кількісні показники SWE $\epsilon$ незалежними прогностичними факторами для діагностики РЩ3 [16]. Деякі дослідження повідомляють, що SWE може допомогти розрізнити доброякісні та злоякісні мікромодулі щитоподібної залози [17]. Усі мета-аналізи прийшли до висновку, що SWE $є$ корисним доповненням до звичайного УЗД ЩЗ для прогнозування злоякісного захворювання ЩЗ. Був зроблений висновок, що SWE може бути корисним при відборі пацієнтів з вузлами ЩЗ для хірургічного втручання $[18,19]$. ТАПБ $є$ широко

прийнятою процедурою для діагностики вузлових захворювань ЩЗ. Проте, зважаючи на інвазивність цього методу, доцільним є використання SWE в диференційній діагностиці доброякісних та злоякісних вузлових утворень Щ3, що може зменшити кількість ТАПБ на 60,8 \% [20].

Наводимо клінічні випадки з практики.

Пацієнтка К. Доброякісний вузол щитоподібної залози.

Ехографічна характеристика (В-режим): додаткове утворення, без капсули, змішаної ехоструктури, з чітким контуром, васкуляризований «губчастий вузол». Ехоморфологічний тип вузла - колоїдний вузол другого типу, вірогідність злоякісності 0 \%. Категорія за шкалою THIRADS THIRADS 2. Показів до ТПАБ немає (рис. 1).

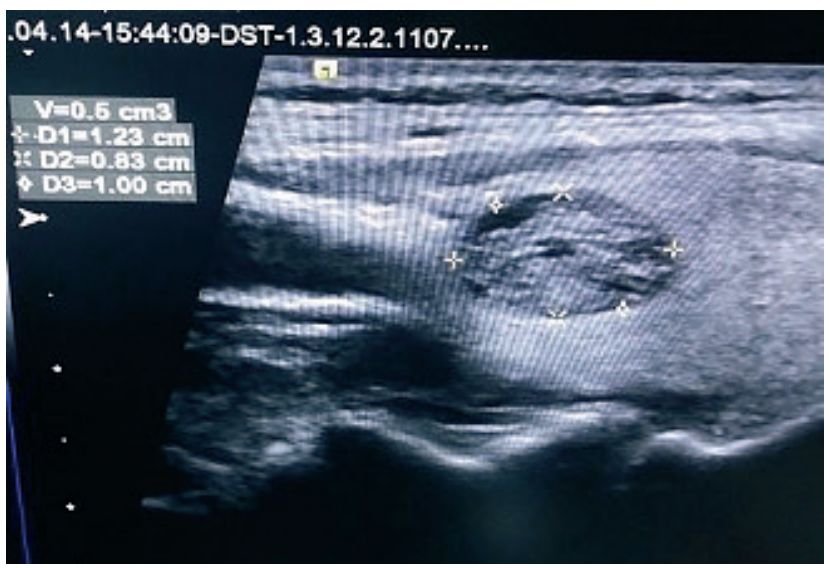

Рис. 1. Уз-зображення щитоподібної залози у B-режимі. Вузловий зоб. THIRADS 2.

Еластографічна картина: кольорове картування відповідає другому типу (картується мозаїчним синім, зеленим, фіолетовим) - доброякісне утворення (рис. 2), ділянки підвищеної жорсткості вузла не відмічаються (швидкість зсувної хвилі нижча 2,4 м/с) (рис. 3).

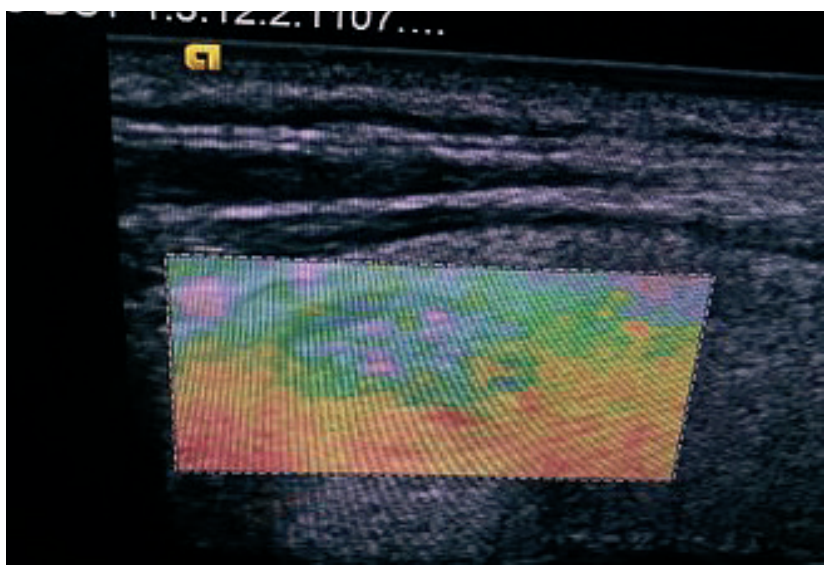

Рис. 2. У3-зображення зсувнохвильової еластографії, кольорове картування. Вузол картується по другому типу - доброякісне утворення. 
Огляди літератури, оригінальні дослідження, погляд на проблему, випадок з практики, короткі повідомлення

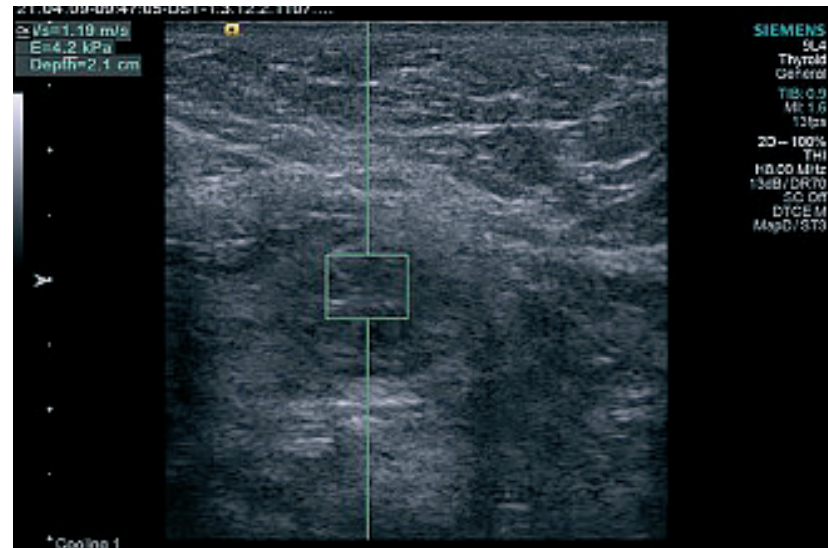

Рис. 3. УЗ-зображення зсувнохвильової еластографії. Жорсткість вузла низька (швидкість проходження зсувної хвилі нижча 2,4 м/с).

Пацієнтка П. Гіпертрофований фолікул

Ехографічна характеристика (В-режим) (рис. 4): анехогенне утворення з гіперехогенними включеннями з "хвостом комети», без кровопостачання. Ехоморфологічний тип вузла - колоїдний вузол першого типу, вірогідність злоякісності 0 \%. Категорія за шкалою THIRADS - THIRADS 2. Показань до ТПАБ немає.

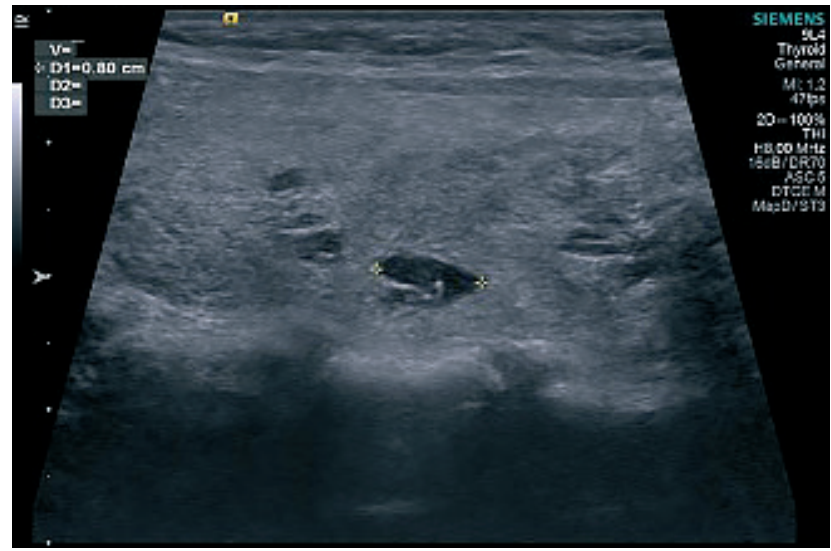

Рис. 4. Уз-зображення щитоподібної залози у B-режимі. Колоїдний вузол першого типу. THIRADS 2.

Еластографічна картина: кольорове картування відповідає другому типу (картується мозаїчним синім, зеленим, фіолетовим) - доброякісне утворення (рис. 5), показники швидкості не відображаються у зв'язку із проходженням ультразвукової хвилі в рідині (рис. 6). лози.

Пацієнт Л. Злоякісний вузол щитоподібної за-

Ехографічна характеристика (В-режим): додаткове утворення, гіпоехогенне, з нечітким контуром, вертикально орієнтоване, гіповаскуляризоване. Ехоморфологічний тип вузла - злоякісний, вірогідність злоякісності $90 \%$. Категорія за шкалою THIRADS - THIRADS 46 (рис. 7). Рекомендовано проведення ТАПБ.

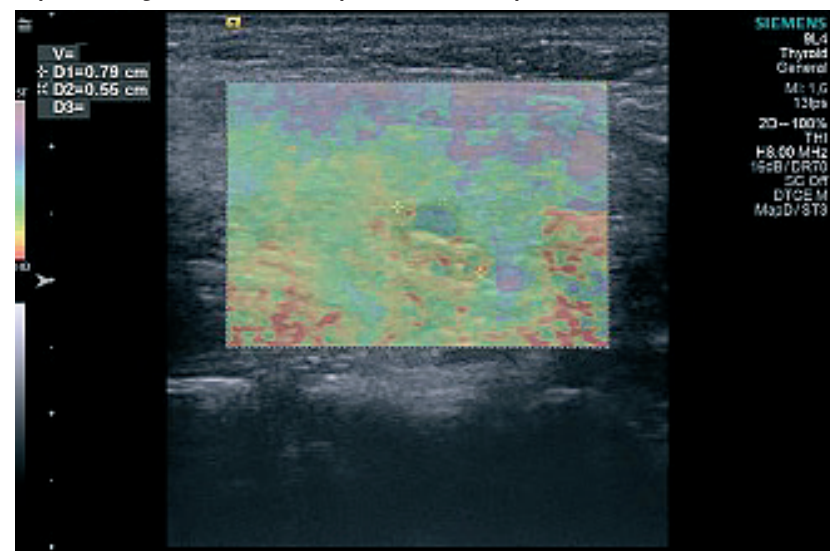

Рис. 5. УЗ-зображення зсувнохвильової еластографії, кольорове картування. Колоїдний вузол картується по другому типу - доброякісне утворення.

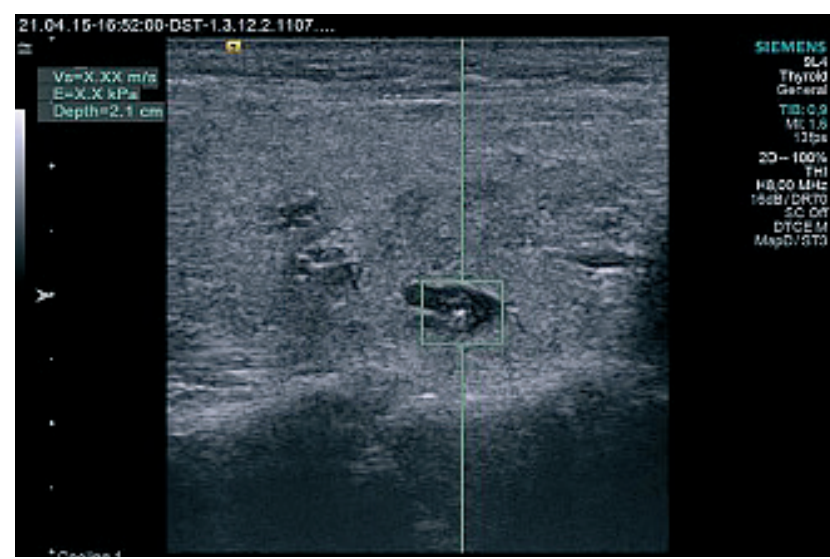

Рис. 6. УЗ-зображення зсувнохвильової еластографії. Показники швидкості не відображаються у зв'язку із проходженням ультразвукової хвилі в рідині.

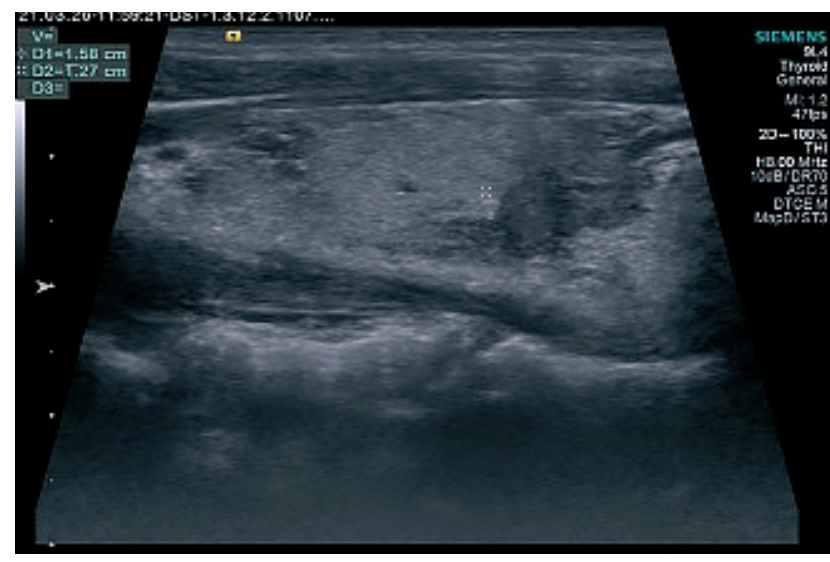

Рис. 7. УЗ-зображення щитоподібної залози у В-режимі. Вузловий зоб. THIRADS 46.

Еластографічна картина: кольорове картування відповідає четвертому типу (картується червоно-жовтим кольором з перевагою червоного) - високий ступінь ризику злоякісного утворення (рис. 8), відмічаються ділянки підвищеної жорсткості вузла (швидкість зсувної хвилі вища 2,4 м/с). 
Огляди літератури, оригінальні дослідження, погляд на проблему, випадок з практики, короткі повідомлення

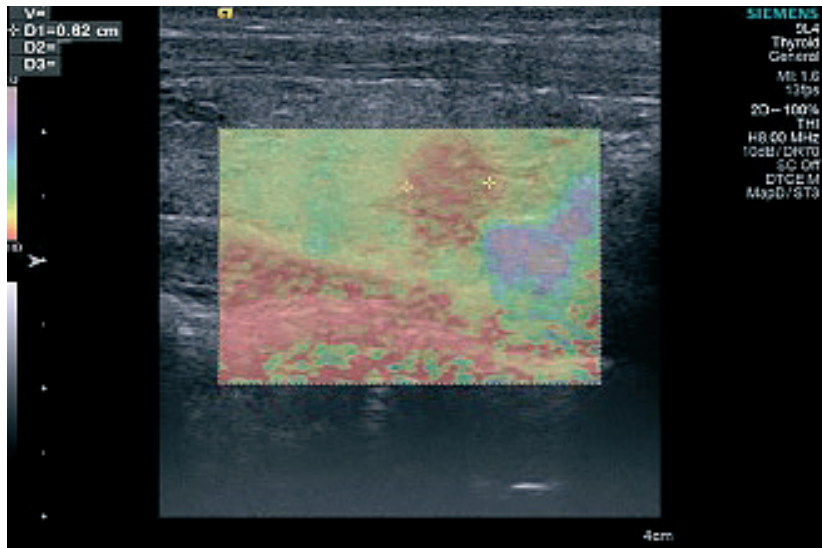

Рис. 8. Уз-зображення зсувнохвильової еластографії, кольорове картування. Вузол картується за четвертим типом - високий ступінь ризику злоякісного утворення.

\section{Пацієнтка П. Автоімунний тиреоїит.}

Ехографічна характеристика (В-режим): ехоструктура паренхіми ЩЗ неоднорідна, ехогенність - знижена (рис. 9), кровопостачання - не посилене.

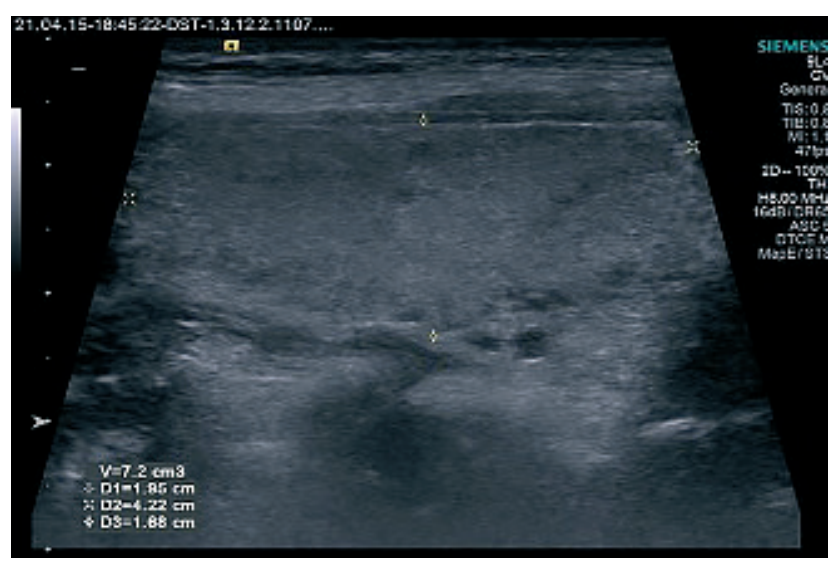

Рис. 9. Уз-зображення щитоподібної залози у В-режимі. Автоімунний тиреоїдит.

Еластографічна картина: при кольоровому картуванні паренхіма ЩЗ картується зеленим i, незначно, жовто-червоним кольорами (рис. 10), швидкість поширення зсувної хвилі вища 2,4 м/с (відповідає підвищеній жорсткості паренхіми залози) (рис. 11).

Пацієнт С. Дифузний токсичний зоб.

Ехографічна характеристика (В-режим): ехоструктура паренхіми щ3 неоднорідна, ехогенність знижена (рис. 12), кровопостачання посилене (рис. 13).

Еластографічна картина: при кольоровому картуванні паренхіма ЩЗ картується жовто-червоним i, незначно, зеленим кольорами (рис. 14), швидкість поширення зсувної хвилі вища $2,4 \mathrm{~m} / \mathrm{c}$ (відповідає підвищеній жорсткості паренхіми залози) (рис. 15).

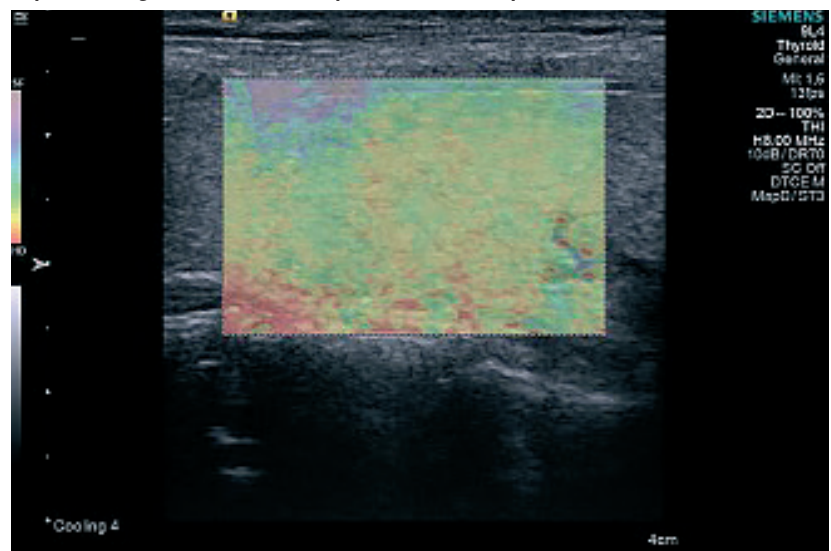

Рис. 10. Уз-зображення зсувнохвильової еластографії, кольорове картування. Паренхіма залози картується зеленим, жовтим та червоним кольорами. Автоімунний тиреоїдит.

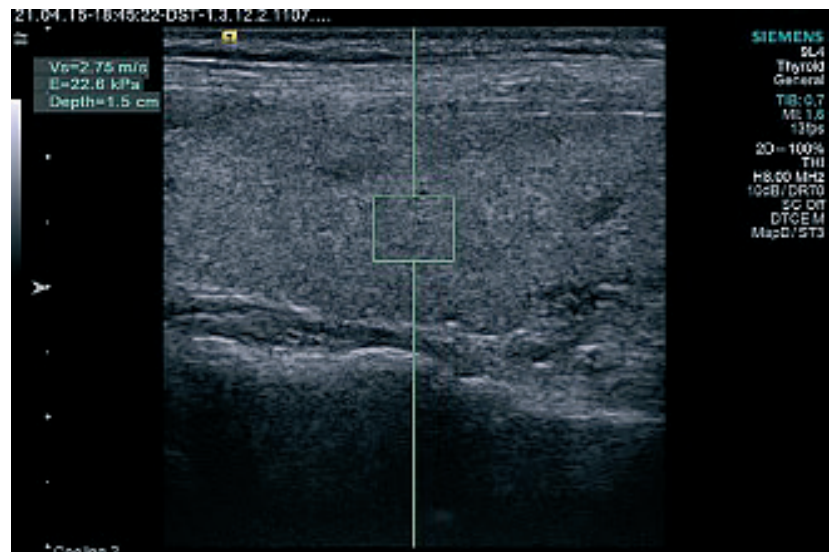

Рис. 11. Уз-зображення зсувнохвильової еластографії. Швидкість поширення зсувної хвилі при проходженні через паренхіму залози вища 2,4 м/с (відповідає підвищеній жорсткості). Автоімунний тиреоїдит.

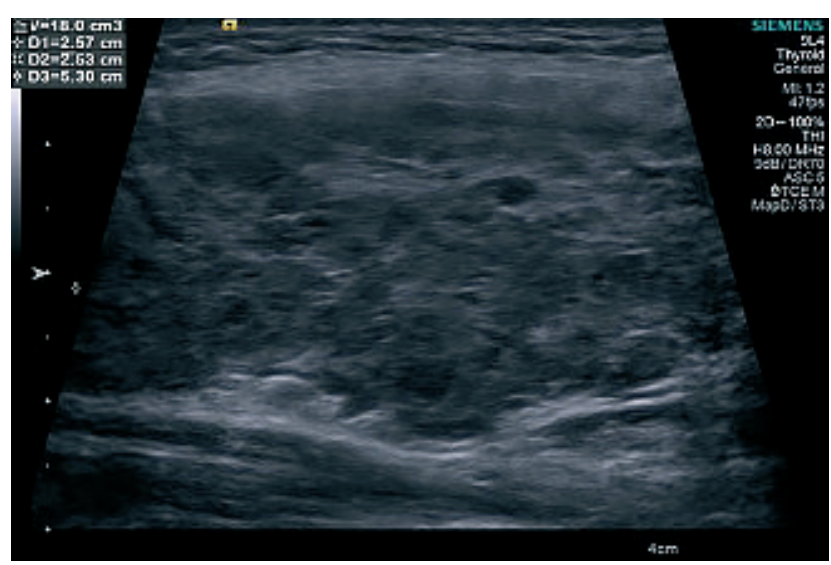

Рис. 12. Уз-зображення щитоподібної залози у В-режимі. Дифузний токсичний зоб. 
Огляди літератури, оригінальні дослідження, погляд на проблему, випадок з практики, короткі повідомлення

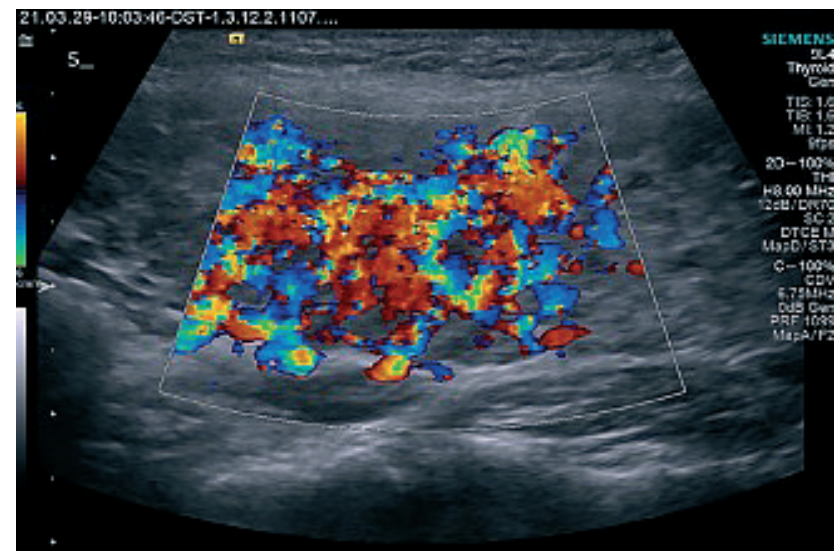

Рис. 13. Уз-зображення щитоподібної залози у режимі кольорової доплерографії. Дифузний токсичний 306.

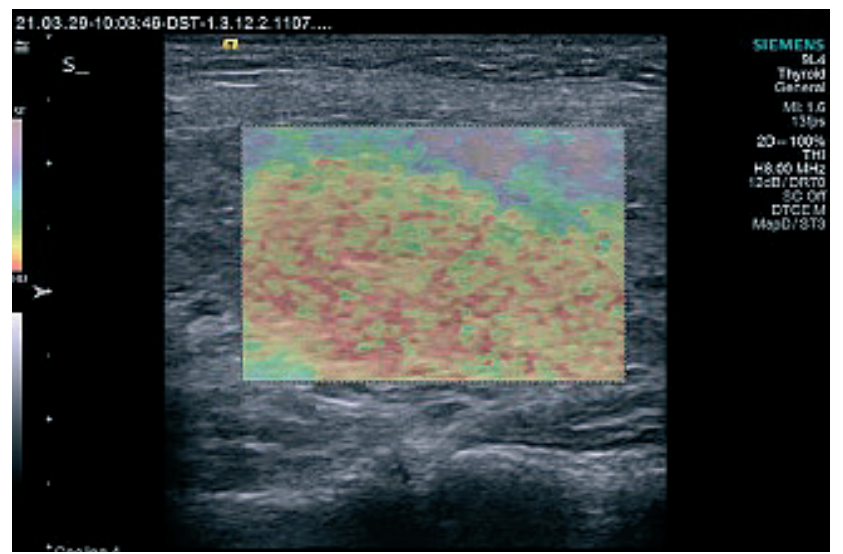

Рис. 14. Уз-зображення зсувнохвильової еластографії, кольорове картування. Паренхіма залози картується червоним, жовтим та, в незначній кількості, зеленим кольорами. Дифузний токсичний зоб.

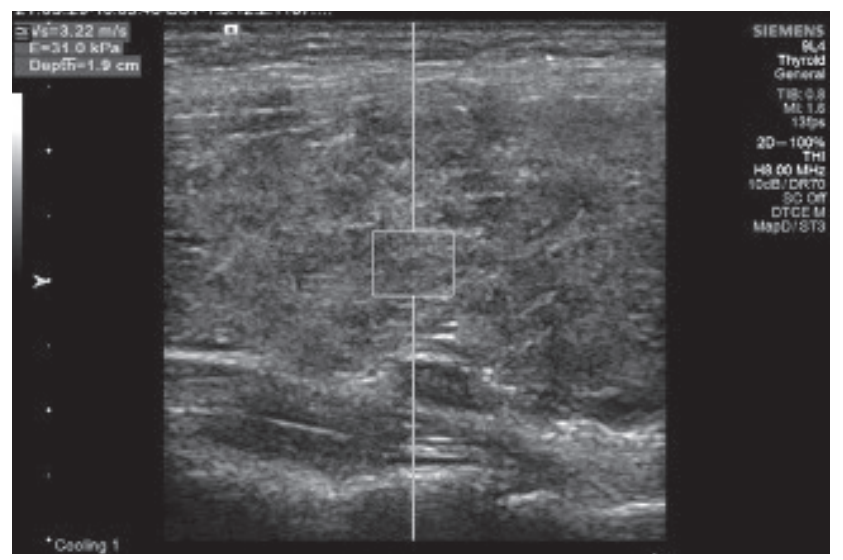

Рис. 15. У3-зображення зсувнохвильової еластографії. Швидкість зсувної хвилі при проходженні через паренхіму залози вища 2,4 м/с (відповідає підвищеній жорсткості). Дифузний токсичний зоб.

Загалом автоімунний тиреоїдит (АIT) та хвороба Грейвса діагностуються відповідно до клінічних і лабораторних даних. Спорея та ін. повідомили, що між особами з нормальною щз та пацієнтами з AIT та хворобою Грейвса $\epsilon$ суттєві відмінності в SWE зі значеннями $(2,07 \pm 0,44)$ м/с проти $(2,68 \pm$ 0,50) м/с відповідно. Однак суттєвої різниці між АІТ та хворобою Грейвса не виявлено $((2,82 \pm 0,47)$ м/с в порівнянні з $(2,49 \pm 0,48)$ м/с). Показники швидкості проходження зсувної хвилі через тканину $\epsilon$ недостовірними для диференційної діагностики AIT та хвороби Грейвса. Лю та співавт. також виявили, що при SWE не вдається відрізнити AIT та хворобу Грейвса [21]. Фукухара та ін. виявили, що показник SWE у пацієнтів з AIT $(2,47 \pm 0,57$ м/с) був значно вищим, ніж у контрольних групах $(1,59 \pm$ 0,41 м/с). Чутливість, специфічність та точність діагностики становили 90,6 \%, 78,7 \% та 85,1 \% відповідно. Тому SWE може бути корисним для діагностики дифузних захворювань щЗ та оцінки ступеня фіброзу її паренхіми [22].

У Міжнародних рекомендаціях з еластографії наводять середні показники швидкості проходження зсувної хвилі через тканину (SWE) для ЩЗ у нормі - $(1,6 \pm 0,18)$ м/с, при доброякісних вузлах $(2,55 \pm 0,28)$ м/с і $(1,72 \pm 0,31)$ м/с, при злоякісних утвореннях - $(2,66 \pm 0,95)$ м/с. Інтервал значень для диференційної діагностики між доброякісним та злоякісним утворенням складає від 2,4 до 4,7 м/с. Чіткого зв' язку зміни жорсткості та діаметра вогнища не показано (рекомендації № 21, 22, 23). О6меження в використанні SWE включають дуже великі та маленькі вузли, кальцинати та кістозні зони (рекомендація № 26). Виміри при SWE можуть бути утруднені в непапілярних карциномах ЩЗ (рекомендація № 24) [3].

Згідно з дослідженнями, проведеними в нашій клініці, середні показники швидкості зсувної хвилі при проходженні через тканину складали: у

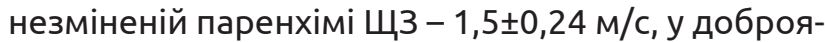
кісних вузлах - 1,8 0,56 м/с, при підозрі на злоя-

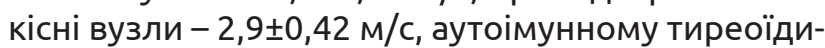

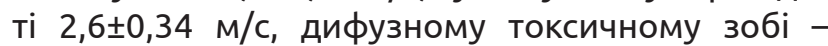

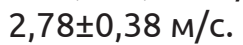

Висновки. 1. Вимірювання швидкості зсувної хвилі та кольорове картування при проведенні зсувнохвильової еластографії дозволяють підвищити ефективність ранньої діагностики доброякісних та злоякісних утворень щитоподібної залози за рахунок їх різної жорсткості.

2. Автоімунний тиреоїдит та дифузний токсичний зоб характеризуються підвищеними показниками швидкості проходження зсувної хвилі через паренхіму щитоподібної залози, що може використовуватись як додатковий критерій у встановленні діагнозу.

3. Зсувнохвильова еластографія - інформативний, неінвазивний, безпечний метод дослідження, який, в поєднанні із обстеженням у 
Огляди літератури, оригінальні дослідження, погляд на проблему, випадок з практики, короткі повідомлення В-режимі та режимі доплерографії, дозволяє підвищити ефективність диференційної діагностики різних захворювань щитоподібної залози.

Перспективи подальших досліджень. Отримані результати можуть стати передумовою для

подальших досліджень з вивчення кореляційних взаємозв' язків між функціональним станом ЩЗ, даними УЗД ЩЗ та еластографії.

\section{ЛІТЕРАТУРА}

1. Дрижак В. І. Стан діагностики та лікування первинного раку печінки / В. І. Дрижак, І. В. Жулкевич, І. М. Леськів // Вісник наукових досліджень. - 2013. № 2. - C. 72-73.

2. Differentiation of benign and malignant thyroid nodules by using comb-push ultrasound shear elastography: a preliminary two-plane view study / A. Gregory, M. Bayat, V. Kumar [et al.] // Acad. Radiol. - 2018. Vol. 25 (11). - P. 1388-1397.

3. Comb-push ultrasound shear elastography (CUSE) for evaluation of thyroid nodules: preliminary in vivo results / M. Mehrmohammadi, P. Song, D. D. Meixner [et al.] // IEEE Trans. Med. Imaging. - 2015. - Vol. 34 (1). - P. 97-106.

4. Elastography: a quantitative method for imaging the elasticity of biological tissues / J. Ophir, I. Cespedes, H. Ponnekanti [et al.] // Ultrason Imaging. - 1991. Vol. 13 (2). - P. 111-134.

5. Thyroid gland tumor diagnosis at US elastography / A. Lyshchik, T. Higashi, R. Asato [et al.] // Radiology. 2005. - Vol. 237 (1). - P. 202-211.

6. Shear wave elastography: a new ultrasound imaging mode for the differential diagnosis of benign and malignant thyroid nodules / F. Sebag, J. Vaillant-Lombard, J. Berbis [et al.] // J. Clin. Endocrinol. Metab. - 2010. Vol. 95 (12). - P. 5281-5288.

7. The values of shear wave elastography in avoiding repeat fine-needle aspiration for thyroid nodules with nondiagnostic and undetermined cytology / L. Chen, Y. X. Shi, Y. C. Liu [et al.] // Clin. Endocrinol. (Oxf). - 2019. Vol. 91 (1). - P. 201-208.

8. Utility of shear wave elastography to detect papillary thyroid carcinoma in thyroid nodules: efficacy of the standard deviation elasticity / H. J. Kim, M. K. Kwak, I. H. Choi [et al.] // Korean J. Intern. Med. - 2019. Vol. 34 (4). - P. 850-857.

9. Diagnostic performance of shear wave elastography in the identification of malignant thyroid nodules: a meta-analysis / P. Lin, M. Chen, B. Liu [et al.] // Eur. Radiol. 2014. - Vol. 24 (11). - P. 2729-2738.

10. Sun J. Real-time ultrasound elastography for differentiation of benign and malignant thyroid nodules: a metaanalysis / J. Sun, J. Cai, X. Wang // J. Ultrasound. Med. - 2014. - Vol. 33 (3). - P. 495-502.

11. The use of ultrasound elastography in the assessment of malignancy risk in thyroid nodules and multinodular goitres / A. Rivo-Vazquez, A. Rodriguez-Lorenzo, J. E. Rivo-Vazquez [et al.] // Clin. Endocrinol. (Oxf). - 2013. Vol. 79 (6). - P. 887-891.
12. 2015 American Thyroid Association management guidelines for adult patients with thyroid nodules and differentiated thyroid cancer: the American Thyroid Association Guidelines. Task force on thyroid nodules and differentiated thyroid cancer / B. R. Haugen, E. K. Alexander, K. C. Bible [et al.] // Thyroid. -2016. - Vol. 26 (1). P. 1-133.

13. American Association of Clinical Endocrinologists, American College of Endocrinology, and Associazione Medici Endocrinologi Medical guidelines for clinical practice for the diagnosis and management of thyroid nodules: 2016 update / H. Gharib, E. Papini, J. R. Garber [et al.] // Endocr. Pract. - 2016. - Vol. 22 (5). - P. 622-639.

14. EFSUMB guidelines and recommendations on the clinical use of ultrasound elastography. Part 2: Clinical applications / D. Cosgrove, F. Piscaglia, J. Bamber [et al.] // Ultraschall Med. - 2013. - Vol. 34 (3). - P. 238-253.

15. WFUMB guidelines and recommendations on the clinical use of ultrasound elastography: part 4. Thyroid / D. Cosgrove, R. Barr, J. Bojunga [et al.] // Ultrasound Med. Biol. - 2017. - Vol. 43 (1). - P. 4-26.

16. Preoperative prediction of papillary thyroid microcarcinoma via multiparameter ultrasound / H. J. Ma, J. C. Yang, Z. P. Leng [et al.] // Acta Radiol. - 2017. Vol. 58 (11). - P. 1303-1311.

17. Diagnostic value of elastosonography for thyroid microcarcinoma / H. Wang, L. Zhao, X. Xin [et al.] / Ultrasonics. - 2014. - Vol. 54 (7). - P. 1945-1949.

18. Diagnostic value of two-dimensional shear wave elastography in papillary thyroid microcarcinoma / S. B. Duan, J. Yu, X. Li [et al.] // Onco Targets Ther. - 2016. Vol. 9. - P. 1311-1317.

19. Acoustic radiation force impulse imaging (ARFI) for differentiation of benign and malignant thyroid nodules: a meta-analysis / J. Zhan, J. M. Jin, X. H. Diao, Y. Chen // Eur. J. Radiol. - 2015. - Vol. 84 (11). P. 2181-2186.

20. Utility of the ultrasound elastographic systolic thyroid stiffness index in reducing fine-needle aspirations / M. Dighe, J. Kim, S. Luo, Y. Kim // J. Ultrasound. Med. - 2010. - Vol. 29 (4). - P. 565-574.

21. The value of shear wave elastography in diffuse thyroid disease / J. Liu, Y. Zhang, Y. Ji [et al.] // Clin. Imaging. - 2018. - Vol. 49. - P. 187-192.

22. Correlation between quantitative shear wave elastography and pathologic structures of thyroid lesions / T. Fukuhara, E. Matsuda, Y. Endo [et al.] // Ultrasound Med. Biol. - 2015. - Vol. 41 (9). - P. 2326-2332. 


\section{REFERENCES}

1. Dryzhak, V.I., Zhulkevych, I.V., \& Leskiv, I.M. (2013). Stan diahnostyky ta likuvannia pervynnoho raku pechinky [Status of the diagnosis and treatment of primary liver cancer]. Visnyk naukovykh doslidzhen - Bulletin of Scientific Research, 2, 72-73. DOI: https://doi.org/10.11603/24158798.2013.2.5768 [in Ukrainian].

2. Gregory, A., Bayat, M., Kumar, V., Denis, M., Kim, B.H., Webb, J., \& Alizad, A. (2018). Differentiation of benign and malignant thyroid nodules by using comb-push ultrasound shear elastography: a preliminary two-plane view study. Acad Radiol., 25 (11), 1388-1397. DOI: 10.1016/j.acra.2018.02.025

3. Mehrmohammadi, M., Song, P., Meixner, D.D., Fazzio, R.T., Chen, S., Greenleaf, J.F., \& Alizad, A. (2015). Comb-push ultrasound shear elastography (CUSE) for evaluation of thyroid nodules: preliminary in vivo results. IEEE Trans. Med. Imaging, 34 (1), 97-106. DOI: 10.1109/ TMI.2014.2346498

4. Ophir, J., Cespedes, I., Ponnekanti, H., Yazdi, Y., \& Li, X. (1991). Elastography: a quantitative method for imaging the elasticity of biological tissues. Uttrason Imaging, 13 (2), 111-134. DOI: 10.1177/016173469101300201

5. Lyshchik, A., Higashi, T., Asato, R., Tanaka, S., Ito, J., Mai, J.J., ..., \& Togashi, K. (2005). Thyroid gland tumor diagnosis at US elastography. Radiology, 237 (1), 202-211. DOI: 10.1148/radiol.2363041248

6. Sebag, F., Vaillant-Lombard, J., Berbis, J., Griset, V., Henry, J.F., Petit, P., \& Oliver, C. (2010). Shear wave elastography: a new ultrasound imaging mode for the differential diagnosis of benign and malignant thyroid nodules. J. Clin. Endocrinol. Metab., 95 (12), 5281-5288. DOI: $10.1210 /$ jc.2010-0766

7. Chen, L., Shi, Y.X., Liu, Y.C., Zhan, J., Diao, X.H., Chen, Y., \& Zhan, W.W. (2019). The values of shear wave elastography in avoiding repeat fine-needle aspiration for thyroid nodules with nondiagnostic and undetermined cytology. Clin. Endocrinol. (Oxf), 91 (1), 201-208. DOI: 10.1111/cen.13992

8. Kim, H.J., Kwak, M.K., Choi, I.H., Jin, S.Y., Park, H.K., Byun, D.W., \& Yoo, M.H. (2019). Utility of shear wave elastography to detect papillary thyroid carcinoma in thyroid nodules: efficacy of the standard deviation elasticity. Korean J. Intern. Med., 34 (4), 850-857. DOI: 10.3904/kjim.2016.326

9. Lin, P., Chen, M., Liu, B., Wang, S., \& Li, X. (2014). Diagnostic performance of shear wave elastography in the identification of malignant thyroid nodules: a meta-analysis. Eur Radiol., 24 (11), 2729-2738. DOI: 10.1007/s00330014-3320-9

10. Sun, J., Cai, J., \& Wang, X. (2014). Real-time ultrasound elastography for differentiation of benign and malignant thyroid nodules: a metaanalysis. J. Ultrasound. Med., 33 (3), 495-502. DOI: 10.7863/ultra.33.3.495

11. Rivo-Vazquez, A., Rodriguez-Lorenzo, A., RivoVazquez, J.E., Paramo-Fernandez, C., Garcia-Lorenzo, F., Pardellas-Rivera, H., \& Gil-Gil, P. (2013). The use of ultrasound elastography in the assessment of malignancy risk in thyroid nodules and multinodular goitres. Clin. Endocrinol. (Oxf), 79 (6), 887-891. DOI: 10.1111/cen.12219

12. Haugen, B.R., Alexander, E.K., Bible, K.C., Doherty, G.M., Mandel, S.J., Nikiforov, Y.E., \& Wartofsky, L. (2016). 2015 American Thyroid Association management guidelines for adult patients with thyroid nodules and differentiated thyroid cancer: the American Thyroid Association Guidelines. Task Force on Thyroid Nodules and Differentiated Thyroid Cancer. Thyroid, 26 (1), 1-33. DOI: $10.1089 /$ thy.2015.0020

13. Gharib, H., Papini, E., Garber, J.R., Duick, D.S., Harrell, R.M., Hegedus, L., \& Vitti, P. (2016). American Association of Clinical Endocrinologists, American College of Endocrinology, and Associazione Medici Endocrinologi Medical guidelines for clinical practice for the diagnosis and management of thyroid nodules: 2016 update. Endocr. Pract., 22 (5), 622-639. DOI: 10.4158/EP161208.GL

14. Cosgrove, D., Piscaglia, F., Bamber, J., Bojunga, J., Correas, J.M., Gilja, O.H., \& Dietrich, C.F. (2013). EFSUMB guidelines and recommendations on the clinical use of ultrasound elastography. Part 2: Clinical applications. Ultraschall Med., 34 (3), 238-253. DOI: 10.1055/s-0033-1335375

15. Cosgrove, D., Barr, R., Bojunga, J., Cantisani, V., Chammas, M.C., Dighe, M., \& Dietrich, C.F. (2017). WFUMB guidelines and recommendations on the clinical use of ultrasound elastography: part 4. Thyroid. Ultrasound Med. Biol., 43(1), 4-26. DOI: 10.1016/j.ultrasmedbio.2016.06.022

16. Ma, H.J., Yang, J.C., Leng, Z.P., Chang, Y., Kang, H., \& Teng, L.H. (2017). Preoperative prediction of papillary thyroid microcarcinoma via multiparameter ultrasound. Acta Radiol., 58(11), 1303-1311. DOI: 10.1177/0284185117692167

17. Wang, H., Zhao, L., Xin, X., Wei, X., Zhang, S., Li, Y., \& Gao, M. (2014). Diagnostic value of elastosonography for thyroid microcarcinoma. Ultrasonics, 54 (7), 1945-1949. DOI: $10.1016 /$ j.ultras.2014.04.027

18. Duan, S.B., Yu, J., Li, X., Han, Z.Y., Zhai, H.Y., \& Liang, P. (2016). Diagnostic value of two-dimensional shear wave elastography in papillary thyroid microcarcinoma. Onco Targets Ther., 9, 1311-1317. DOI: 10.2147/OTT.S98583

19. Zhan, J., Jin, J.M., Diao, X.H., \& Chen, Y. (2015). Acoustic radiation force impulse imaging (ARFI) for differentiation of benign and malignant thyroid nodules: a meta-analysis. Eur. J. Radiol., 84 (11), 2181-2186. DOI: 10.1016/j.ejrad.2015.07.015

20. Dighe, M., Kim, J., Luo, S., \& Kim, Y. (2010). Utility of the ultrasound elastographic systolic thyroid stiffness index in reducing fine-needle aspirations. J. Ultrasound Med., 29 (4), 565-574. DOI: 10.7863/jum.2010.29.4.565

21. Liu, J., Zhang, Y., Ji, Y., Wan, Q., \& Dun, G. (2018). The value of shear wave elastography in diffuse thyroid disease. Clin. Imaging., 49, 187-192. DOI: 10.1016/j.clinimag.2018.03.019

22. Fukuhara, T., Matsuda, E., Endo, Y., Takenobu, M., Izawa, S., Fujiwara, K., \& Kitano, H. (2015). Correlation between quantitative shear wave elastography and pathologic structures of thyroid lesions. Ultrasound Med. Biol., 41 (9), 2326-2332. DOI: 10.1016/j.ultrasmedbio.2015.05.001 


\author{
○Н. В. Скрипник ${ }^{1}$, Л. В. Рибчак ${ }^{1}$, В. М. Казьмирук², Х. З. Лаврук ${ }^{1}$,
} А. З. Братина ${ }^{2}$, Т. И. Власюк ${ }^{1}$

\author{
${ }^{1}$ Ивано-Франковский национальный медицинский университет \\ 2Лечебно-диагностический центр Святого Луки Ивано-Франковского Архиепархиального Управления УГКЦ
}

РЕзюМЕ. В статье приведены обзор литературы и данные, полученные нами в результате наблюдения за 1549 пациентами с патологией щитовидной железы (ЩЖ) с помощью эластографии сдвиговой волны на клинической базе Ивано-Франковского национального медицинского университета в Лечебно-диагностическом центре Святого Луки Ивано-Франковского Архиепархиального Управления УГКЦ.

Цель - анализ данных эластографии сдвиговой волны для совершенствования дифференциальной диагностики патологий щитовидной железы.

Материал и методы. УЗИ проводили на аппаратах Siemens Acuson S3000 и Siemens Acuson S2000 с использованием линейного датчика (с частотой 9 МГц) в В-режиме, режиме цветной допплерографии и эластографии сдвиговой волны.

Результаты. Эластография играет важную роль в диагностике и наблюдении за заболеваниями щитовидной железы. В статье приведены клинические случаи эхографических характеристик и эластографии сдвиговой волны доброкачественных и злокачественных узлов, аутоиммунного тиреоидита, диффузного токсического зоба.

Выводы. Эластография сдвиговой волны - это новый метод, развивающийся в клинической практике, который позволяет различить доброкачественные и злокачественные узловые образования щитовидной железы, является полезным дополнением для прогнозирования злокачественного заболевания, независимым прогностическим фактором для диагностики рака щитовидной железы.

КЛЮЧЕВЫЕ СЛОВА: щитовидная железа; узловые заболевания щитовидной железы; эластография сдвиговой волны; диагностика.

\title{
THE ROLE OF ULTRASOUND ELASTOGRAPHY IN THE EVALUATION OF THYROID DISEASES
}

\author{
@N. V. Skrypnyk', L. V. Rybchak' ', V. M. Kazmiruk², Kh. Z. Lavruk', A. Z. Bratyna², T. I. Vlasiuk ${ }^{1}$ \\ ${ }^{1}$ Ivano-Frankivsk National Medical University \\ 2St. Luke's Medical Diagnostic Center of Ivano-Frankivsk Archdiocesan Administration \\ of Ukrainian Greek Catholic Church
}

SUMMARY. The article reviews the literature and presents personal data of observations of 1549 patients with thyroid gland pathology, using shear wave elastography at the clinical base of Ivano-Frankivsk National Medical University at the St. Luke's Medical Diagnostic Center of Ivano-Frankivsk Archdiocesan Administration of Ukrainian Greek Catholic Church. gies.

The aim - to analyze the data of shear wave elastography to improve the differential diagnosis of thyroid patholo-

Material and Methods. Ultrasound examination was performed on a Siemens Acuson S3000 and a Siemens Acuson S2000 using a linear sensor (9 MHz) in B-mode, color Doppler mode and shear wave elastography.

Results. Elastography plays an important role in the diagnosis and monitoring of thyroid disease. The article presents clinical cases of ultrasound characteristics and shear wave elastographic picture of benign and malignant nodes, autoimmune thyroiditis, diffuse toxic goiter.

Conclusions. Shear wave elastography is a new method that is being developed in clinical practice and can help to distinguish between benign and malignant thyroid nodules, is a useful adjunct for predicting thyroid malignancy, an independent prognostic factor for the diagnosis of thyroid cancer.

KEY WORDS: thyroid gland; nodular diseases of the thyroid gland; shear wave elastography; diagnosis.

Отримано 06.05.21 